\title{
The Social and Local Dimensions of Governance of Energy Poverty: Adaptive Responses to State Remoteness
}

\author{
N. Creutzfeldt ${ }^{1}$ (D) $\cdot$ C. Gill ${ }^{2} \cdot$ R. McPherson ${ }^{2} \cdot$ M. Cornelis $^{3}$
}

Received: 16 August 2019 / Accepted: 13 December 2019 / Published online: 11 January 2020

(C) The Author(s) 2020

\begin{abstract}
Energy poverty is a huge social problem. Academic and policy deliberations about energy poverty focus repeatedly on the same issues: the lack of a shared definition, who is responsible for the problem, and how best to measure it through indicators. We argue that debates at EU and national level do not address the daily reality of people living in energy poverty. The preliminary findings of our ESRC funded project suggest that local actors (e.g., NGOs) make a substantial contribution to bridging the gap between top-down policy and the energy poor. We argue that these actors represent an adaptive response to the inherent limitations of state and supra-national action and, therefore, play a key role in the governance of energy poverty. In presenting this argument, we suggest, as an avenue for future research, nodal governance as a lens through which to understand the role local actors play in the governing order for tackling energy poverty. The article provides an exploratory analysis of these issues, discussed through the selection of four illustrative examples in Italy, France, Catalonia, and England.
\end{abstract}

Keywords Consumer law $\cdot$ nodal governance $\cdot$ energy poverty $\cdot$ third sector

Energy poverty is a form of poverty with adverse consequences for people's health and wellbeing. It represents a significant social problem, with potentially great future impact on the climate resilience of those affected. Energy poverty is widespread across Europe: ${ }^{1} 50$ million Europeans cannot afford to keep their homes warm in winter; 100 million cannot keep their homes cool in summer; and seven million receive disconnection notices every year (Right

\section{${ }^{1}$ Retrieved from: https://www.energypoverty.eu/about/what-energy-poverty}

N. Creutzfeldt

n.creutzfeldt@westminster.ac.uk

1 University of Westminster, London, United Kingdom

2 University of Glasgow, Scotland, United Kingdom

3 Turin, Italy 
to Energy coalition 2019). Different terms are used to describe affected persons: fuel poor, energy poor, vulnerable energy consumers or, in a broader sense, at-risk-of-poverty or lowincome people. ${ }^{2}$ The European Union (EU) and national governments have put in place measures to address this problem. The aim of this article is to map out and assess these measures, and then to provide an exploratory examination of the vital role that local, community-based, and third-sector organizations play in helping to ensure that consumers living in energy poverty are able to access help and advice. ${ }^{3}$ What is their contribution in the complex mix of supra-national and state level measures currently in place to tackle energy poverty? Can they provide part of the multi-faceted solution required to meet the challenge placed by such a complex policy problem? If so, what may their particular contribution be and how do they relate and respond to formal measures?

EU-level policies create a framework to shape member states' approaches to energy poverty. Some member states have policies in place to tackle energy poverty, others do not. The choice of action taken varies and is "tailored to national circumstances characterized by the policy approach, extent of market liberalization, and physical characteristics of household energy and building stock" (Pye and Dobbins 2015, p. vi). All of this makes an EU, top-down, coordinated response challenging. A particular challenge is created by the competing frames of energy poverty, with the problem being framed and addressed in very different ways: as a public health matter; as a concern of energy market transformation; as a matter of economic wellbeing; as an aspect of climate change mitigation; as an aspect of housing policy; as a question of social security; and, at its broadest, as a matter of ethics. This multiple framing recognizes the complex and crosscutting nature of the issue, but can result in inaction as issues get stuck in silos and responsibilities get redirected.

The argument of this article is that local, community-based, third-sector organizations play a key role in helping energy poor consumers access help and advice, and by doing so represent an adaptive response to the inability of law and policy to address the complex and multi-faceted problem of energy poverty. This adaptive response has both bottom-up and top-down elements: Local initiatives have developed to meet unmet demand for help and, at the same time, state actors have recognized the value of local actors and sought to co-opt them as a tool for addressing energy poverty. Indeed, a number of local initiatives now exist across Europe that seek to help consumers: navigate the energy market; access low-interest loans for home improvements; learn about energy efficiency and energy savings; and prepare for sustainable consumption in a low-carbon future. Our argument is that state and supra-national policies are unable to tackle energy poverty alone and that these grassroots initiatives, based at a local level and within communities, represent an important site at which energy poverty is being addressed. These initiatives fill gaps not currently addressed by law and policy, while at the same time providing a bridge that state and supra-national policymakers can harness to reach energy poor individuals and communities. This local dimension of energy poverty, therefore, represents a dynamic site of interaction, where state and local actors seek to address energy poverty and in which adaptive solutions are developed in response to the

\footnotetext{
${ }^{2}$ Tackling Fuel Poverty in Europe, Recommendations Guide for Policy Makers". Report produced in the framework of the Intelligent Energy Europe project EPEE- European Fuel Poverty and Energy Efficiency, September 2009.

${ }^{3}$ It is based on our project on energy poverty and vulnerability in Europe, see https://esrcjustenergy.wordpress. com.
} 
scale of the challenge which energy poverty presents and which cannot be addressed alone by any single actor.

In developing this argument, we examine four jurisdictions, with different policy approaches and third sector arrangements: France, Italy, England ${ }^{4}$, and Catalonia. First, we provide an overview of energy poverty measures in each jurisdiction, before presenting illustrative examples of local initiatives designed to highlight the type and variety of activities undertaken by these actors. In France, we highlight the development of a complex network of diffuse, state, local, third sector and commercial actors which work together to address energy poverty; in England and Catalonia, we discuss the way in which third-sector delivery provides a vehicle for the implementation of state level policies; and in Italy, we examine a corporate social responsibility (CSR) linked charitable project. What all these actors and initiatives share is a local, community-based, and bottom-up presence. Whereas government actors struggle to reach the most vulnerable, local actors are awarded trust in their function of assisting local communities and are better placed to provide help and advice to those who need it most. This local level of governance provides a site of exchange between state-level and local actors, where the state's financial resources and institutional capacity meet local actors' expertise, community knowledge, and ability to access individuals who are unlikely to engage with formal institutions.

Local actors, working as part of networks which include government actors, charities, NGOs, and energy companies, can use their key roles within this governance framework to influence government policy and push for change, at the same time as assisting with the delivery of existing measures and taking independent action where current state action is lacking. This local level of governance, we argue in the conclusion, can be understood as fitting within two broader themes of contemporary public policy: the development of an EU-wide 'civil society' that aims to pick up the pieces from neoliberalism; and second, the undervalued role of community and civil society in addressing energy poverty. In discussing our illustrative examples and setting out these exploratory ideas, we particularly emphasize the importance of actors working through networks as an important mechanism of governance. Thus, we propose nodal governance as a framework through which future research can be conducted and sketch out the contribution that this framework makes to understanding the governance of energy poverty policy.

This paper has five parts. The first part maps the policy landscape at EU and national level. The second part presents the methodology. The third presents selected local initiatives, as illustrative examples. The fourth introduces nodal governance and the last part concludes the paper.

\section{Mapping the Policy Landscape}

Pye and Dobbins (2015) note that less than a third of EU member states explicitly recognize the concept of energy poverty and only four countries have legislated definitions (United Kingdom, Ireland, France, and Cyprus). Those member states that recognize energy

\footnotetext{
${ }^{4}$ Various aspects of energy poverty policy in the United Kingdom, apply across the country, while others are devolved and, therefore, different in England, Scotland, Wales, and Northern Ireland. The summary provided here relates to the situation in England, as the UK's largest jurisdiction.
} 
poverty see it as a linked yet distinctive problem from vulnerable consumer protection. In the next two sections we discuss EU and national measures to fight energy poverty in turn.

\section{EU Legislation}

The issue of energy poverty has only been recognized recently in EU law and policy. The European Parliament recognized the concept of 'energy poverty' during the discussions of the Third Energy Package relating to common rules for the internal electricity and gas markets, adopted in 2009 (Directives 2009/72/EC and 2009/73/EC). The 2009 Directives emphasizes subsidiarity, requiring member states to adopt vulnerable consumer definitions and protective measures that fitted their national contexts (Article 3 (7) \& (8) of 2009/72/EC). The European Commission suggests that vulnerable households could be defined as those spending too much - possibly twice as much as the average - on energy products, and households that have difficulties in paying their energy bills (Directives 2009/72/EC and 2009/73/EC). More recently, with the Clean Energy Package (2018-2019), EU member states have to adopt a definition of energy poverty, considering income levels, share of energy expenditure of disposable income, energy efficiency of homes, critical dependency on electrically powered equipment for health reasons, age or other criteria. Member States must monitor the phenomenon and propose appropriate measures (Governance Regulation 2018/1999). The elements included in the definitions will have a prevalence at the political level, allowing for specific categories of people to be more protected than others and to use different budgetary lines. Overall, there has been a move between the Third Energy Package and the Clean Energy Package towards explicitly recognizing energy poverty rather than considering the question as one of consumer vulnerability.

EU policymakers, however, face serious challenges in addressing energy poverty. A major issue relates to questions of definition and measurement which are often driven by the availability of data ${ }^{5}$ (Thomson and Snell 2016). Conceptualizing and defining energy / fuel poverty is a necessary first step before creating measurement indicators: "who is fuel poor depends on the definition; but the definition depends on who you want to focus on and this involves political judgement" (Boardman 2010, p. 21). Pye et al. (2017, p. 262) note that "limited co- ordinated actions at the European level are in place, for three key reasons - 1) the problem is not yet fully understood (shortcomings in existing indicators); 2) action to date has been guided by the principle of subsidiarity, and 3) the EC competency is focused on vulnerable consumers in regulated markets, not on households in energy poverty across the wider energy system. As a result, its recognition and understanding is limited to few Member States". Additionally, definitions vary by Member State to include a broad group of consumers who are at a disadvantage navigating the energy market as well as individual households that are at risk of energy poverty.

A further issue for policymakers is that energy poverty is a cross-cutting issue that lies at the intersection of many distinct policy fields. Is energy poverty a social problem, a (public) health problem, or an environmental problem? Each of these areas are governed by different policies,

\footnotetext{
${ }^{5}$ The lack of a definition and the resulting lack of consistency in the available data makes analyzing and comparing levels of energy poverty an impossible task. Even National Regulatory Authorities do not have the same mandate throughout Europe to handle energy poverty and vulnerability data because this is the task of social security institutions or other bodies.
} 
budgets and political priorities. This reality makes it challenging to find the best solution for individuals living in energy poverty, who usually experience energy poverty as a cluster of other problems. It is perhaps not surprising in this context that EU level policy, despite some positive recent developments, appears to be inherently limited in its scope and ambitions.

\section{National Measures in Governing Policy on Energy Poverty}

In most EU countries, vulnerable customers are protected through a combination of energy specific measures and social security benefits. Many EU member states make use of winter truce $^{6}$ and restrictions to disconnection to protect vulnerable consumers. Although EU regulations are closing in on the definition of energy poverty and measures to fight it, law and policy interventions varied across our case studies (England, France, Italy and Catalonia). It is also the case that in some jurisdictions national action on energy poverty preceded EU action and is more far reaching than the minimal requirements of EU law. We focus below on comparing definitions of energy poverty; measures of energy poverty; energy efficiency; and policy initiatives. The section closes by assessing these developments and concluding that significant challenges lie in the way of addressing energy poverty.

\section{Definitions of Energy Poverty}

Italy does not have an official (binding) definition of energy poverty. However, the National Energy Strategy (launched in $2017^{7}$ ) defines energy poverty as the "difficulty of purchasing a minimum set of energy goods and services or access to energy services that implies a diversion of resources, in terms of expenditure or income, higher than a normal value."

\section{Actions Taken Against Energy Poverty}

In Italy, despite the existence of measures designed to reduce the energy bill (energy bonuses for electricity and gas), the enforcement of energy poverty mitigation measures is lagging at the national level. Regulated tariffs are still the norm, as the regulator keeps postponing a complete market opening. Energy prices for domestic consumers in Italy are high due to the high level of energy imports and dependency on foreign sources, and the cost for renewables support schemes ( $€ 12.1$ bn in 2018 or 0.7 pp of GDP). Extra costs, such as the tax on public television, are applied to bills, creating misunderstandings, confusion, and mistrust in the market, and a massive disengagement of energy consumers (Canalenergia 2019).

In France, energy poverty is a phenomenon that is well understood, analysed and acknowledged by public authorities and companies. The four main factors that can lead to fuel poverty are a low level of resources, low-performance housing (poor insulation and inadequate heating equipment when available), energy prices, and household practices (Law n ${ }^{\circ} 2010-788$ of 12 July 2010 on National Commitment to the Environment). The French approach to energy poverty is highly integrated, thanks to a large number of generous redistributive measures, such as a solidarity income (RSA) or housing subsidies (APL); as well as targeted programmes

\footnotetext{
${ }^{6}$ Energy suppliers are not allowed to disconnect households during the winter period (November - March) from electricity or natural gas provision. For more information: https://www.energypoverty.eu/measure-policy/wintertruce.

${ }^{7}$ Retrieved from https://www.eera-set.eu/wp-content/uploads/Italian-National-Energy-Strategy-2017.pdf.
} 
to combat energy poverty. They are mainly focused on the quality and energy performance of the dwelling.

Catalonia has its own distinct developments on energy poverty that are discussed here but put in context of Spanish law. The Spanish Law 24/2013 on the electricity sector prohibits the interruption of the supply for the persons who have medical treatment at home, where the use of an electric appliance is essential (they only need to provide a medical certificate). Law 24/ 2013 of the electricity sector and the Royal Decree 897/2017 guarantee the provision to people using social services in a situation of social exclusion. The 2015 Catalan law 24/2015 on energy poverty goes further, involving a series of stakeholders, including the town social services and energy companies directly. The consumer can also report the undue cut-off to the municipal or regional public consumption service (the Regional Consumer Information Offices and the Municipal Consumer Information Offices). The Consumer Code (Codi de Consum) Catalan Law 22/2010, LLEI 22/2010 envisages penalties for companies violating the law, since it may constitute an administrative infringement.

In England, a number of provisions seek to tackle energy poverty. The Fuel Poverty Regulations 2014 set the following target: "to ensure that as many as is reasonably practicable of the homes in which such persons live have a minimum energy efficiency rating of Band C as determined by the Fuel Poverty Energy Efficiency Rating Methodology”. In 2015, the government published its updated fuel poverty strategy: Cutting the Cost of Keeping Warm. Progress against the strategy is monitored by the Committee on Fuel Poverty (CFP).

An important recent policy initiative has been the introduction of a price cap, which Ofgem is devising and implementing. Price capping measures are complemented by a range of other regulatory interventions by Ofgem, for example, its Consumer Vulnerability Strategy (2013) and the Fuel Poor Networks Extension Scheme (PNES). Another strand of policy involves the provision of cash payments to customers who are at risk of fuel poverty. The Warm Homes Discount scheme requires medium and large energy suppliers to support people who are living in fuel poverty or a fuel poverty risk group by providing rebates. In relation to social security payments, Winter Fuel Payments were introduced in 1997 to help older people meet the costs of heating their homes in winter.

Energy poverty has increasingly been recognized as a public health issue in England. Measures here are delivered by both health organizations and local authorities. The Care Act 2014 requires that the suitability of housing is considered when assessing wellbeing. Public Health England meanwhile has published a Cold Weather Plan for England: Protecting Health and Reducing Harm from Cold Weather which is supported by guidance for clinical staff within the health service on how issues related to energy poverty should be considered as part of the provision of clinical care.

\section{Energy Efficiency}

Despite the requirements of Directive 2018/2002 on Energy Efficiency ("Energy efficiency measures must be central to any cost-effective strategy to address energy poverty and consumer vulnerability and are complementary to social security policies at Member State level"), many countries do not have programmes to combat inefficiency among households affected by energy poverty.

France has developed an inclusive approach focusing on energy efficiency improvements for "modest homeowners" (ANAH) and redistributive policies via the "Chèque énergie". The primary tool for retrofitting and improving the quality of the dwelling is the national housing 
agency ANAH's Living Better Serenity programme established in 2017. 52,268 households have renovated their homes through this programme. It aims to improve the thermal performance of private housing by providing dedicated support to energy-poor occupants. It translates into works subsidies, an additional grant (Prime Habiter Mieux), and a Zero Rate Loan (Eco-Loan Habiter Mieux). Although not explicitly designed for households affected by fuel poverty, some energy suppliers (EDF, Engie, Direct Energie) can also offer significant loans for renovation work.

These measures are financed in part by energy saving certificates (EEC) for which energy producers contribute directly. The French National Energy and Climate plan (NECP) specifies that more than $€ 2$ billion should be invested by energy companies in the fight against energy poverty for the period 2018-2020. The plan for the energy renovation of buildings also foresees that the State will allocate $€ 1.2$ billion to the fight against energy poverty. In the social housing sector, the objective is to renovate "thermal sieves" at a rate of 100,000 per year by multiplying innovative solutions, with a budget of $€ 3$ billion as part of the Grand Plan d'Investissement.

In England, government has legislated to improve energy efficiency in the private rented sector. The key measure is the Energy Company Obligations (ECOs), which oblige energy companies to provide energy efficiency measures for certain customers. The current ECO scheme (ECO 3) requires suppliers to help low income, fuel poor, and vulnerable households heat their homes. The UK NECP mentions that the Energy Company Obligation (ECO) goes up to $£ 640$ million per annum. For 2018-2022, the scheme will be focused entirely on low income and vulnerable households. The Energy Efficiency (Private Rented Property England and Wales) Regulations 2015 establish a minimum level of energy efficiency for privately rented property in England. Another intervention in relation to energy efficiency is found in the Home Energy Conservation Act 1995, which places a statutory duty on local authorities to take action in relation energy efficiency of residential properties and report every two years to the Department for Business Energy and Industrial Strategy (BEIS).

\section{Policy and Initiatives}

In France, the fight against fuel poverty is characterized by an extensive network of well-coordinated actors, the RAPPEL. ${ }^{8}$ A law in 2011 created an energy poverty observatory ${ }^{9}$ which aims to monitor the phenomenon, find indicators, and best practices of the sector. The energy poverty observatory identified seventeen main measures, divided into building, personal or energy support policies (ONPE 2019). The "Chèque énergie" is a payment voucher intended for low-income households, enabling them to pay their energy bills or perform small renovation work in their homes. The "chèque énergie" gradually replaced the social energy tariffs (for electricity and gas) and was spread in 2018 to cover a broader scope. All modes of heating can be purchased with it (electricity, gas, fuel oil, LPG, wood), which challenges their impact on the development of more sustainable energies. In total, 3.6 million households in France benefitted from the "chèque énergie" (compared to 3 million for social tariffs) in 2018. However, the amount of the chèque énergie is judged as insufficient by

\footnotetext{
${ }^{8}$ Retrieved from https://www.precarite-energie.org.

${ }^{9}$ Retrieved from https://www.legifrance.gouv.fr/affichTexte.do?cidTexte=JORFTEXT000022470434 \&categorieLien=id; http://onpe.org/lobservatoire_national_de_la_precarite_energetique.
} 
NGOs, social services and consumer organizations. It adds a level of complexity and burdens households with more bureaucracy. ${ }^{10}$

The Spanish strategy's indicators focus on household expenditures, affordability, ability to heat in the winter and cool in the summer, and pays particular attention to regional disparities. It is very welcome in a country with a wide variety of climates and significant temperature differences, and large autonomy of certain regions, such as Catalonia. It translates into a fragmented national policy landscape, often challenged by regulatory overlaps and tensions between the Spanish and Catalan lawmakers. Catalan organizations gathered around the Alliance against energy poverty ${ }^{11}$ have been campaigning for a long time for the recognition of the regional characteristics of energy poverty. They drove the Catalan Law 24/2015 which establishes a series of measures to guarantee the right of access to drinking water, lighting and gas supply for people and family units at risk of residential exclusion (Generalitat de Catalunya, 2015). The municipality of Barcelona is taking a strong lead on the issue by supporting the Catalan Congress on Energy Poverty and the creation of energy assessment points in partnership with local NGOs, such as Ecoserveis. The issue of energy efficiency or retrofitting measures is, so far, only tackled at the local level with pilot projects, such as the Caf-Acció project also led by Ecoserveis in Catalonia. However, the new national strategy could lead to more plans to improve the quality of buildings (EPOV 2019).

At the Spanish State level, the social bonus was created in 2009 as a mechanism to support the payment of electricity bills by vulnerable families ${ }^{12}$. This system offers a 25 per cent discount on the bill to certain types of consumers: households with a minimum contracted power of three kilowatts, large families, pensioners with minimum benefits and households with only unemployed members. The social bonus is a discount that is applied only on the voluntary price for small consumers (PVPC), the flexible regulated price for small consumers since April 2014. ${ }^{13}$ Electricity providers are financing the social bonus as part of their public service obligation. Electricity suppliers shall fund at least 50 percent of the amount of the bills of severely vulnerable consumers (who are being cared for by social services of a regional or local government).

In England, other local bodies with a key statutory role in preventing fuel poverty include Health and Wellbeing Boards, which act as a forum in which key leaders from the local health and care system work together to improve the health and wellbeing of their local population. Policy in England also includes key strategic requirements and programmes that seek to support third sector partnerships to reduce energy poverty. This is reflected in the government's fuel poverty strategy and in specific interventions such as the Big Energy Saving Network, a $£ 1.7$ million/ year scheme jointly funded by the Department of Business, Energy and Industrial Relations designed to help third sector organizations support vulnerable energy consumers and community groups.

\footnotetext{
${ }^{10}$ Challenges, 2019 Le nouveau chèque énergie laisse les associations sur leur faim https://www.challenges. fr/energie-et-environnement/la-hausse-du-cheque-energie-pas-suffisante-pour-les-ong_650164.

${ }^{11}$ Retrieved from https://pobresaenergetica.es/index.php/ca/.

12 Resolución de 26 de junio de 2009, de la Secretaría de Estado de Energía, por la que se determina el procedimiento de puesta en marcha del bono social, see https://www.boe.es/buscar/doc.php?id=BOE-A-200910672.

${ }^{13}$ Resolución de 31 de enero de 2014, de la Dirección General de Política Energética y Minas, por la que se revisa el coste de producción de energía eléctrica y los precios voluntarios para el pequeño consumidor, see https:/www.boe.es/boe/dias/2014/02/01/pdfs/BOE-A-2014-1053.pdf. According to the supplier Endesa, currently, half of the Spanish households, or 13 million points of delivery, benefit from regulated prices https://www.endesaclientes.com/mercado-libre-mercado-regulado-pvpc.
} 


\section{Assessing Policy Interventions: The Challenge of Addressing Energy Poverty}

In Italy, the main measures addressing energy poverty, the electricity and gas bonuses, only impact bill payments and have little influence on energy poverty levels (Faiella and Lavecchia 2014). If they represent a temporary relief for low-income families and people relying on life-saving medical equipment, they fail to address the inadequacies of the dwelling and the root causes of energy poverty. The regulatory authority Autorità di Regolazione per Energia reti e Ambiente (ARERA) estimates that, to date, only about a third of potential beneficiaries have asked for the energy bonus, and attributes the low levels of use to various factors. These, according to the draft of the NECP 2019 submitted by the Italian Government, include a lack of awareness of the measure itself and the administrative complexity of the requirements. The regulator pushes to remove bureaucratic barriers and introduce automated tools for granting financial support to reach all potential beneficiaries. A draft law could lead to an automatic attribution, but some actors already warned of the burden on other consumers. The controversial "citizenship income" (Reddito di cittadinanza) ${ }^{14}$, entered into force in April 2019, could lead to an automatic allocation of the bonus.

In Italy, a national observatory on energy poverty ${ }^{15}$, Osservatorio Italiano sulla Povertà Energetica (OIPE), was launched in February 2019. Despite this being a promising development, there does not appear to be any coordination of the actors on the ground. Challenges to help energy poor consumers in Italy are the vast geographical and climatic disparities; lack of relevant information (Canalenergia 2019); significant decentralization and the general lack of investment in the issue of the state and the regulator. Additional answers and more integrated solutions are therefore offered at the municipal and regional levels, in combination with companies, foundations and associations. ${ }^{16}$

In France, the measures are financed in part by energy saving certificates (EEC) for which energy producers contribute directly. Energy companies should invest more than $€ 2$ billion in the fight against energy poverty for the period 2018-2020. The plan for energy renovation of buildings also foresees that the State will allocate $€ 1.2$ billion to fight energy poverty. In the social housing sector, the objective is to renovate "thermal sieves" at a rate of 100,000 per year. However, members of the RAPPEL network, NGOs and activists believe that the government's retrofitting ambition remains too low, in particular for renters, and the amount of the Cheque Energie is not sufficient to make a difference for the most vulnerable (CLER 2019).

In Catalonia, the main problems are linked to the political tensions with the government of Madrid. The policy landscape is challenged by regulatory overlaps and tensions between the Spanish and Catalan lawmakers. Catalan laws protect individuals and households at risk against disconnection by the electricity, gas and drinking water suppliers due to failure to pay. Utilities cannot cut the supply off on the grounds of non-payment in the event of a risk of residential exclusion ${ }^{17}$. However, even though energy laws are managed at the national level,

\footnotetext{
${ }^{14}$ Retrieved from https://www.redditodicittadinanza.gov.it.

${ }^{15}$ Retrieved from http://oipeosservatorio.it/.

${ }^{16}$ For instance, pilot projects implemented at the regional level (Lotta alla Povertà energetica with Leroy Merlin in Piedmont, Tutor per l'energia domestica or TEDs thanks to European funds in Rome and Milan), or with the support of energy companies (such as the project Banco dell'energia with A2A in Lombardy) are relatively well received, but no local measures seem to be in place.

${ }^{17}$ Generalitat de Catalunya. Guia per a persones i famílies que tenen problemes econòmics per mantenir els subministraments d'aigua, llum i gas (Guide for people and families who have financial problems to maintain water, electricity and gas supplies). Retrieved from https://web.gencat.cat/web/shared/GENCAT/que_cal_fer_ si/serveis_centrals/que_fer_quan_especials/queferquan/pobresa-energetica/GUIA-POBRESA-ENERGETICAdoc_10638282_1.pdf (accessed 6 November 2019).
} 
three bills govern energy poverty management and prohibit the suspension of the electricity supply in Catalonia: the Spanish Law 24/2013 on the Electricity Sector, the Catalan Law 24/ 2015 on energy poverty and the Royal Decree 897/2017. This situation creates enforcement issues and limits the impact of the prohibition of disconnection of the energy supply on vulnerable households.

Besides, the social bonus is criticized for being too complex, poorly designed and not comprehensive enough (Síndic de Greuges de Catalunya 2018; HISPACOOP 2017). The conditions to apply are too numerous, the lack of automatization and the need to apply every two years hamper its impact, and despite being extended to other categories, single-parent families are not covered.

In England, despite the number of measures in place and the number of actors involved in this policy area, the challenges of tackling fuel poverty are significant and progress in this area has not been as extensive as it might be. There have also been criticisms of certain policy interventions. For example, the Committee on Fuel Poverty (the Committee) argued in their latest annual report that progress was stalling in meeting fuel poverty reduction targets, with mixed results on key measures. For example, since introducing the strategy in 2014/ 2015 the number of households in fuel poverty has risen by 210,000 to reach 2.5 million, while the UK BEIS estimates show that progress on upgrading the energy efficiency of fuel poor homes is 2 per cent to 6 per cent lower than previously forecast. Concerns have been expressed about other dimensions of policy, such as the effectiveness of public health measures and the extent to which they are being implemented in practice (NEA Action for Warm Homes 2016).

In sum, each of the jurisdictions described above takes measures to address energy poverty. Some of the jurisdictions are more advanced than others in developing this work, but all face significant challenges in address energy poverty. It is in this context that the rest of this paper turns to examining the role of local actors.

\section{Methodology}

Four jurisdictions are the case studies for this paper. The selection was supported by a combination of existing contacts (access) and to ensure a contrast of geographical and jurisdictional spread. While these selection criteria were largely pragmatic, the sampling choices were seen as having two distinct advantages. First, as shown in the Tables 1 and 2 above, each jurisdiction has different approaches to the definition of energy poverty and to the range and type of policies designed to address energy poverty. Second, each jurisdiction has different institutional structures of government and a differently composed charitable/third sector, as well as different approaches to national and regional policy-making. As a result, the country sample was considered to include a range of relevant contexts and to include a helpful range of potentially different experiences in relation to the local governance of energy poverty.

The data presented and discussed below is extracted from a larger dataset, which is being added to through ongoing data collection. ${ }^{18}$ In this article, we seek to explore emerging themes from our data analysis, as a preliminary to further data collection and analysis. In drawing out these reflections on the role of local actors in energy poverty governance, the article seeks to identify and interrogate this important theme in our data.

$\overline{18}$ This broader data set currently includes 45 interviews (35 with NGOs and 10 with policymakers). 
Table 1 Official definitions of energy poverty

\begin{tabular}{|c|c|}
\hline $\begin{array}{l}\text { England } \\
\text { (since 2013) }\end{array}$ & $\begin{array}{l}\text { "A household where i) their income is below the poverty line (taking into account energy } \\
\text { costs); and ii) their energy costs are higher than is typical for their household type." }\end{array}$ \\
\hline $\begin{array}{l}\text { France (since } \\
\text { 2010) }\end{array}$ & $\begin{array}{l}\text { "Is considered in a situation of energy poverty "a person who encounters in his/her accom- } \\
\text { modation particular difficulties to have enough energy supply to satisfy his/her elementary } \\
\text { needs, this being due to the inadequacy of resources or housing conditions." }\end{array}$ \\
\hline \multirow[t]{3}{*}{$\begin{array}{l}\text { Spain (since } \\
\text { 2019) }\end{array}$} & $\begin{array}{l}\text { "Energy poverty is the situation in which a household cannot meet its basic energy needs, } \\
\text { as a result of an insufficient income level and which, where appropriate, may be aggravated } \\
\text { by having an energy inefficient dwelling }\end{array}$ \\
\hline & $\begin{array}{l}\text { Energy poverty may manifest through a variety of factors, such as the inability to maintain an } \\
\text { adequate temperature in the home, late payment of bills, excessively low energy } \\
\text { expenditure or expenditure on energy supplies that is disproportionate to the level of } \\
\text { income. }\end{array}$ \\
\hline & $\begin{array}{l}\text { Vulnerable consumers are consumers of electrical energy or thermal services who find } \\
\text { themselves in a situation of energy poverty, and may be beneficiaries of support measures } \\
\text { established by administrations." }\end{array}$ \\
\hline
\end{tabular}

Source: Dobbins, A., \& Pye, S. (2016). Member State level regulation related to energy poverty and vulnerable consumers. In k. Csiba (Ed.), Energy poverty handbook (pp. 119-152; see specifically pp. 137-138). The Greens/ EFA Group in the European Parliament. Brussels: European Union

Table 2 Examples of energy poverty measures in each jurisdiction

\begin{tabular}{|c|c|c|c|c|}
\hline & $\begin{array}{l}\text { Reducing the } \\
\text { bill }\end{array}$ & Energy efficiency & $\begin{array}{l}\text { Engaging energy } \\
\text { companies }\end{array}$ & Energy poverty and health \\
\hline Italy & $\begin{array}{l}\text { Energy } \\
\text { bonuses } \\
\text { Regulated } \\
\text { tariffs }\end{array}$ & & & $\begin{array}{l}\text { Energy bonus for people } \\
\text { depending on lifesaving } \\
\text { appliances }\end{array}$ \\
\hline France & $\begin{array}{l}\text { Redistributive } \\
\text { measures } \\
\text { (RSA, } \\
\text { housing } \\
\text { subsidies) } \\
\text { Chèque } \\
\text { énergie }\end{array}$ & $\begin{array}{l}\text { National housing agency } \\
\text { programmes }\end{array}$ & $\begin{array}{l}\text { Energy producers } \\
\text { contribute directly to } \\
\text { Energy saving } \\
\text { certificates (EEC) to } \\
\text { provide energy } \\
\text { efficiency measures }\end{array}$ & \\
\hline Catalonia & Social bonuses & $\begin{array}{l}\text { Mentioned in the } 2019 \\
\text { strategy }\end{array}$ & $\begin{array}{l}\text { Electricity providers are } \\
\text { financing the social } \\
\text { bonus as part of their } \\
\text { public service } \\
\text { obligation }\end{array}$ & $\begin{array}{l}\text { Interdiction of } \\
\text { disconnection for } \\
\text { chronically ill patients }\end{array}$ \\
\hline England & $\begin{array}{l}\text { Cold Weather } \\
\text { Payment } \\
\text { Price cap }\end{array}$ & $\begin{array}{l}\text { ECO programme; Energy } \\
\text { Efficiency (Private } \\
\text { Rented Property } \\
\text { England and Wales) } \\
\text { Regulations } 2015\end{array}$ & $\begin{array}{l}\text { Energy Company } \\
\text { Obligations (ECOs) } \\
\text { oblige energy compa- } \\
\text { nies to provide energy } \\
\text { efficiency measures for } \\
\text { certain customers }\end{array}$ & $\begin{array}{l}\text { Care Act } 2014 \\
\text { Citizens Advice: Local } \\
\text { Authority Toolkit: } \\
\text { Supporting Fuel Poor } \\
\text { and Vulnerable } \\
\text { Households } \\
\text { Public Health England: } \\
\text { Cold Weather Plan for } \\
\text { England: Protecting } \\
\text { Health and Reducing } \\
\text { Harm from Cold } \\
\text { Weather }\end{array}$ \\
\hline
\end{tabular}


Here we present only some illustrative examples and provide interim reflections on the important role of local actors in energy poverty governance. As such the data analysis and the article as a whole are exploratory and provide the building blocks for subsequent research.

The illustrative examples have been selected purposively, as a means of representing interesting and relevant aspects of the operation of local initiatives and their contribution to energy poverty governance. The article makes no claim as to the representativeness of the chosen examples (either against the population of local initiatives nor, indeed, the sample of interview data). Instead, the examples provide the basis for illustrating the way in which local initiatives can be conceptualized as important actors within broader energy poverty networks and recognizing the kinds of contribution they might make to the unmet challenges presented by the problem of energy poverty.

Each illustrative example is based on an in-depth, semi-structured interview with the organization, supplemented by publicly available data and the attendance of the interviewee at a subsequent workshop to discuss third sector involvement in energy poverty governance. We used a form of thematic analysis (Miles et al. 2014), coding, categorizing and summarizing key data in order to identify narratives around local governance in our interview data.

Despite the limitations in our method, we believe that the article adds value in building knowledge about the contribution of the third sector to development and delivery of solutions to energy poverty. The focus on the local teases out important, and relatively overlooked spaces and allows us to understand the complexity that responding to living in energy poverty brings and its complex array of solutions.

\section{The Role of Local Initiatives in Meeting the Challenges of Energy Poverty}

We understand local initiatives that tackle energy poverty as complex, multidirectional sites of encounter, challenge, exchange and interaction. We explore how governance in this area operates in practise through examples below. These examples highlight how local initiatives play an important role in tackling energy poverty. This local governance, we argue, has spread and is part of larger networks as a response to the inability of any single actor to fully tackle the complexities of energy poverty. The local springs up in the spaces between formal policies and fills the spaces where policies fail to reach the ground level. It is also frequently used (and initiated) by formal state actors, who recognize their institutional limitations and value the local access, expertise, and community resources of local actors. The four illustrative examples are presented in two clusters: the first discusses horizontal local networks and the second vertical networks.

\section{Horizontal local networks}

In this part we offer two examples of structures that operate at local level, a charity in the UK and a hybrid structure in Italy. We can trace strategic adaptation to the complexity / challenge energy poverty poses as small projects or initiatives grow into a wider network. 


\section{Middlesbrough Environment City (MEC)}

In the UK we interviewed Middlesbrough Environment City (MEC), a charity that works locally to promote healthy and sustainable living, including affordable warmth. In 2018, MEC's work relating to fuel poverty was funded by a range of public and private organizations.

MEC is part of the Middlesbrough Affordable Warmth Partnership, a network of organizations and charities from across Middlesbrough who work together to give vulnerable residents the help they need to stay warm at home, including: help with fuel switching and energy efficiency; emergency heating; and benefits and welfare advice. MEC also provides one-to-one energy advice and home visits to help vulnerable people.

Typical work delivered by third sector organizations interviewed in the UK involved assisting those in fuel poverty, often on pre-payment metres and needing both emergency help and long-term support. These organizations emphasized the importance of working as part of a network in order to be able to deal with the needs of energy poor consumers. The consumers who approached the organization often had complex needs, including mental health issues, and energy issues might be only one part of the issues they faced. Those who were specialized in energy issues had a leading role in the governance of the network, as the MEC representative evidences:

We've got a partnership that we chair that has got the fire brigade on it; that's got public health, various people from the council, from Citizens Advice Bureau, from Welfare Rights. There's lots of different people who meet, and we have an action plan, a fuel poverty action plan, that we're working towards.

Networks allowed the organization to be part of providing more holistic solutions for people within the locality and to ensure that people could be effectively referred when problems went beyond issues directly connected to energy poverty:

We've had to do a lot of work around referral networks, because obviously we're quite specialised in what we do, and it is very focused on sort of gas and electric, whereas we've had to build up networks to refer on for benefit checks and debt advice. Food bank referrals, you know, just general Citizens Advice information.

Without partnership working, MEC noted that it would be very difficult to help consumers: "I mean, in Middlesbrough we couldn't do it without the partnership.... it does need a partnership approach, because one organisation can't do everything."

UK participants noted that there were a number of reasons why consumers were pushed into energy poverty, including welfare reform and the structure of the energy market. A particular issue was the onus placed on individuals to apply for funds and seek support, which the most vulnerable were simply not in a position to take advantage of. As a result, there was a gap left by formal interventions and policies that could be picked up by charitable organizations that were closer to the ground than more formal actors (whether that be central and local government or health services). Government could do more to help people in fuel poverty, with current support not being sufficient and not being accessible by those most in need:

I think the government should be stepping up a little bit more in terms of their energy efficiency schemes... they're not enough.... the ECO funding is not nearly enough and is requiring... it could be up to a $£ 1,000$ customer contribution, which... is just not possible for most of the clients that we deal with. 
Another problem was that consumers were often in private rented housing, let out by disreputable landlords, and were in a relatively powerless position to demand more energy efficient homes or repairs. Despite landlords having responsibility to take measures and fund improvements, this was difficult for local authorities to enforce and consumers often did not wish to report their landlords.

This was an example where, despite the existence of legislative provisions and responsibilities of formal institutional actors, policies could fail to reach those most in need. The unique contribution of third sector organizations such as MEC was to bridge the gap between formal measures and consumers at need in local communities. Of course, the recognition of the third sector as a key bridging agent in policy delivery is shown in the fact that much of the funding for these organizations is derived from public funds and guided by the need to meet statutory duties.

\section{Lotta alla Povertà Energetica (LPE)}

In Italy there are no national initiatives to tackle energy poverty, apart from an electricity and gas bonus. ${ }^{19}$ In Italy, "energy poverty goes beyond the fuel poverty concept that is being used in the UK: adequate cooling and access to electricity are critical in Italy because of hot summers. It is not only a question of warming up, it's also a question of cooling" (Bank of Italy representative). In addition, several interviewees told us about the poor readability of the Italian billing system, and the overall unstable regulatory framework leading to a disengagement of public powers, local and national governments and the regulator alike:

The power system acts as a hidden fiscal policy: other consumers finance the bonus - $37 \%$ of the bill is about taxes. ${ }^{20}$ It's very dangerous, there's a problem of accountability: invoice prices may increase because of tariffs. It's a regressive policy. When taxes and tariffs are put on an electricity bill, everybody is paying, the firms and the households alike. There's an incompressible minimum due to the taxes and tariffs, and it is very difficult to have a dramatic impact on the amount of the invoice. (AISFOR representative)

The main challenge in Italy is the lack of an integrated approach that involves different parties to look at energy inefficiency. We chose Lotta alla Povertà Energetica (LPE) as an example, a local initiative that is expanding through a larger network and collaborations with other actors from the private and non-profit sectors, and for which energy is not their core business.

There was a shared ambition of Leroy Merlin Italy (DIY retailer) and the Caritas Network to help people with energy saving on the one hand, and address the dramatic growth of people asking for help in paying their energy bills to charities, on the other hand:

We met and I suggested to replicate the Energy Saving Checks scheme in Germany (Stromsparcheck), I was discussing with Politecnico di Torino [Leroy Merlin representative]'. We then decided to carry out the program together as a pilot project in Piemonte, on a target group of 100 households. The University of Torino joined later to support the socio-economic implications of the project.

\footnotetext{
$\overline{19} \mathrm{https} / / / \mathrm{www}$. arera.it/it/consumatori/gas/bonusgas_ec.htm\#valore; This is a discount to help pay the energy bills based on declared income. Retrofitting programmes exist but they are very cumbersome and not specifically targeted at energy-poor. There are many shortcomings in the national approach and measures: public engagement and information awareness plans are missing. The amount granted by the gas bonus depends on the type of use, household size and climatic zone.

${ }^{20}$ Retrieved from https://www.arera.it/it/dati/ees5.htm.
} 
The official project contract involves Leroy Merlin Italy, Politecnico di Torino, Università di Torino and S-Nodi ${ }^{21}$ as a project developer in contact with Caritas representing large institutions. Funding has been entirely provided by Leroy Merlin under the auspice of its Corporate Social Responsibility activities. Actual funding initially includes sponsoring of energy saving devices and the support of some months of research assistants' work.

Starting locally, the pilot in Piedmont, will expand to the national level, thanks to the network of charities distributing food under the European FEAD scheme. ${ }^{22}$ The distribution of devices to some affiliated citizen associations points is another part of the project (Leroy Merlin representative). These are already lending tools, screws and other basic do-it-yourself material to in-need household through an existing collaboration with Leroy Merlin. The aim is to create a national network and expand it further to the European level within the Caritas network. Local energy saving shops could be useful to the whole community, not only the vulnerable: This is the best way to raise awareness on Energy Poverty in the entire community.

The beneficiaries of this project are recipients of the Energy Bonus (discount on the annual bill for low-incomes), but it is difficult to find households to engage with in the long-term. The main difficulty was to find families with housing stability, since there is a very high housing mobility among poor people. It's difficult to have a continuity in the data and the bills of those people. Families stay only for a couple of months in their flats and then move, for instance if they get a work opportunity somewhere else, or if they have trouble paying their rent, they get kicked out or choose to move.

Within LPEs initial target group (100 households) it is a challenge to find households because of the effort it takes to collect and deliver energy bills. It would be ideal to include an energy supplier as partner to assess potential energy savings more easily. LPEs goal is to provide low income households with energy saving devices and make them aware of the meaning and cost of $1 \mathrm{kWh}$ of energy, in order to encourage them to save energy. They also want to provide charities with an assistance protocol for energy poverty that includes notions and operational measures to detect and alleviate most vulnerable situations. In order to take off, the project would need the involvement of the City of Turin, but also to work with the Church, houses for immigrants, and housing cooperatives. Public access to the project has to be broadened. It has to become financially appealing and that is why Politecnico (Milan) is working with Leroy Merlin on business models to sell the EE kits.

In sum, we demonstrated two different models in two different countries that address energy poverty at the local level. In the UK, a charity that directly helps people living in energy poverty as well as helping to sort out related issues. Support is embedded in a structure of advice and hands-on effort with individuals. In Italy, driven by a large company's social responsibility funds, a group of initiatives is enabled to join up and fund a specific project in a selected community.

\section{Vertical Networks}

Two networks discussed here are examples of a complex web of initiatives that form a growing and evolving network that is, compared to the previous examples, spread throughout the

\footnotetext{
${ }^{21}$ Retrieved from https://s-nodi.it.

${ }^{22}$ Retrieved from http://www.lavoro.gov.it/temi-e-priorita/europa-e-fondi-europei/focus-on/fondo-di-aiutieuropei-agli-indigenti-Fead/Documents/2018-FEAD-Country-Fiche-Italy.pdf.
} 
national context. The French example is aimed at educating leaders and decision-makers about energy poverty and the importance to improve living conditions for individuals. The example we chose in Catalonia, in contrast, is aimed at helping the individuals locally with practical holistic solutions.

\section{Rénovons! $!^{23}$}

Environmental associations are very active on the ground of addressing energy poverty, in particular, through the RAPPEL network in France. Most initiatives focus on energy efficiency and the retrofitting of homes. We discuss the Rénovons! (Let's Renovate!) initiative as an example of an initiative that reaches out to other initiatives and builds a specialised network, thereby expanding its resources. Its governance structure becomes an interesting combination of many areas - housing, economic, social, health - to structurally reduce energy poverty.

Rénovons! is an alliance bringing together driving forces of civil society in France, committed to energy efficiency, through energy renovation of housing in France. The members behind the initiative are the Abbé Pierre Foundation, Secours Catholique, SOLIHA - Solidaires pour l'Habitat, CLER - Energy Transition Network ${ }^{24}$, Climate Action Network, Effy Group Schneider Electric Foundation, European Climate Foundation, for example. The Rénovons! initiative raises awareness among decision-makers and the general public about the necessary conditions and existing solutions that will lead to increased quality of energy renovations. They also promote the economic, social, environmental, health benefits of the energy efficiency approach. The renovation of housing, particularly the least energy-efficient ones, should make it possible to structurally reduce fuel poverty. This initiative is well known an appreciated by social workers and public authorities working with people affected by energy poverty, as it works on "the acculturation of actors in order to stop thinking in silos" [Representative of Val-de-Marne].

The Rénovons! initiative aims to bring together a large number of different organizations, thereby creating a network of institutions with different resources and structures; ranging from large companies to the smallest associations, with the general objective in mind to renovate "leaky" houses. Starting in 2016, The Rénovons! initiative has produced a common vision for the renovation of energy sieves in the Renovate Scenario. The initiative has held many meetings, bringing together actors involved in housing renovation and fuel poverty prevention, as well as presidential candidates.

Direct effects of the Rénovons! initiative actions are not assessed at the level of consumers but at the level of the leaders. "We reach dozens of national public decision-makers and probably a few hundred private decision-makers (companies, consultants, intermediaries). In doing so, we implant in their speeches and proposals our ideas which, if not misused (which is

\footnotetext{
${ }^{23}$ Retrieved from http://renovons.org/L-initiative-Renovons.

24 The Rénovons initiative is hosted by the CLER network. CLER - Réseau pour la transition énergétique (formerly Comité de liaison pour les énergies renouvelables) is a French association, approved for the protection of the environment, created in 1984. Its objective is to promote renewable energies, energy management and, more generally, the energy transition. In 2019, CLER will bring together a network of more than 300 professional structures spread throughout France. CLER actors carry out concrete local projects. Within their association, community or company, they implement the energy transition on the ground, using virtuous and replicable local practices. Through the diversity of their activities, nature and fields of action, they contribute to building a transversal and coherent vision of energy.
} 
still too often the case), have positive consequences on the various public policy instruments proposed" [Rénovons representative].

The entanglement of actors can be quite problematic, according to a representative of the Val-de-Marne department (county), close to Paris. There are many actors, which leads to a lot of confusion among households. There is also a very aggressive canvassing on the part of economic actors who try to sell inappropriate services. Many people have financial problems and this undermines trust in public services.

The Rénovons! initiative is an example of an idea that set out to tackle energy poverty through structurally addressing homes and improving them. They reached out to other initiatives and formed a powerful network with resources to provide help for people living in energy poverty locally on the one hand, and to reach out to government and policy to make the debate a tangible one. This initiative is a lobbying and policy development that measures how to tackle energy poverty. Here the 'local' is partly about delivery that supplements national measures to relieve energy poverty on the ground for local people, and partly about building coalitions for systemic change and seeking to influence policy.

\section{ECOSERVEIS}

In Catalonia, we interviewed a public initiative offering personalized support for energy-poor households, on their energy consumption and on measures to reduce it. We discuss local information points, the Punts d'asssessorament energetic (energy information centres), run by ECOSERVEIS for the Municipality of Barcelona. They work locally and are funded by the Barcelona municipality. They are operated by ECOSERVEIS (energy sector non-profit) and ABD (social sector non-profit). The Energy Advice Points project was organised as a public tender on two levels: city management and district management. The city was divided in five areas. The project was awarded to different NGOs on the municipal and district level. Here we have an example of NGOs that work together, producing a larger network, to deliver a service to local people. Their main outlook is to provide information to citizens and part of this is about energy rights and other parts are about general consumer rights information.

One of the main challenges is the lack of information citizens have regarding their energy rights. Therefore, the city council of Barcelona has developed a project supplying Energy Advice Points (EAP). They offer information and help people understand their rights and ensure companies don't deny them access to basic supplies. The points also extend their advice to employment issues (EU Energy Poverty Observatory Case Study 2017). The EAP are very successful and have reached over 20,000 people at the end of 2018. The EAP were set up after two pilot projects. The first was called Energia la Justa (Fair Energy) and trained 100 unemployed vulnerable citizens and employed them for six months as energy advisors. The pilot project reached 3,000 vulnerable households from social services of the city of Barcelona. The energy advisors focused on helping energy poor households to reduce energy bills and implement low cost energy efficiency measures directly in their homes. This pilot started with a synergy with the Horizon 2020 EU funded project with the objective to give support to vulnerable consumers to manage their electricity bills through the smart meter SMARTUP provided manuals, guidelines and know how to enhance both projects.

The second pilot, Punts d'Atenció a la Pobresa Energètica (Energy Attention Points) established four contact points in the city of Barcelona where citizens could go to get energy-related information. The aim of the Energy Attention Points was to detect vulnerable consumers, give advice and if needed provide interventions at the home of households, 
including installation of low-cost energy efficiency measures. The Energy Attention Points project lasted four months and reached 993 people (ECOSERVEIS representative).

The Energy Advice Points project is organised in three main lines of action:

- Energy rights and efficiency;

- Employment; and

- Prevention at community level.

Lessons learned from the EAP are constantly implemented into daily practice:

- Providing information to vulnerable people allows to prevent future energy poverty cases.

- Establishing information points where all citizens can go allow for a better identification of energy poor households than targeted programs.

- Employing advisors that have been in a similar situation facilitates building trust.

- Training through workshops, seminars and giving specific printed information is key to empower energy poor households and prevent future energy poverty cases to happen.

- Facilitating in-home assessments to those that cannot leave the house is crucial to provide information to vulnerable consumers.

- Reaching all citizens can best be done through a flexible approach; for example, in some cases households can be reached better by having their neighbours provide the information.

- Placing the EAPs in housing offices help people know about this service and not relate it with poverty, in order to avoid stigmatization.

Ideally these EAP will be transferred to both smaller and larger municipalities. The city councils could oversee them locally and place them in the housing offices and larger municipalities could bid for a public tender to manage a project on municipality level and neighbourhood levels. It is also advised to involve local environmental and social organizations to enhance community engagement and trust.

The EAP are a good example of a combination of locally endorsed and funded help. It is a combination of initiatives forming a network. They have been piloted and seem to offer the people a combination of help and advice. Although targeted at energy advice, they are have built into their portfolio general advice in matters closely related to the issue of energy poverty: housing. Further initiatives are taken to include local doctors surgeries and fire stations to spread the word about educating consumers about their rights.

\section{Mobilising the Local: A Nodal Governance Approach}

The focus of the paper is on exploring and seeking to identify the particular contribution of local actors to the governance of energy poverty. We now turn to discuss nodal governance as a framework which can could be used to frame these issues in future research and which allows further preliminary insights to be drawn from the illustrative examples above. Nodal governance draws attention to the importance of networks of actors working together and to the complex interactions between actors, each of whom brings different aims, resources, capacities, and expertise to the problem of energy poverty. It also provides a helpful framework for 
understanding the ways in which formal institutions, laws and policies meet and interact with local actors and communities.

Nodal governance allows us to identify a range of governing influences within local networks, with government being a key node but supplemented by other nodes. The local is a level where bottom-up and top-down measures and opportunities meet. As a result, it represents a complex site of governance where formal government explicitly recognizes its limitations and reach, while bottom up actors are both co-opted and empowered by government influence and funding. Government is a key actor/ node in governing the networks at a local level, but the network set-up empowers other actors either through greater expertise, local access, or the use of independent resources (charitable funding, not for profit funding).

Governance is "the management of the course of events in a social system" (Burris et al. 2005 , p.30). Governance places a focus on institutions, social norms and social practises as mechanisms of social systems. A plurality of actors, mechanisms, and rapid adaptive change create new forms of social organization (Burnis et al. 2002; Johnston and Shearing 2003; Roche 2002; Shearing and Burris 2002). To better understand "how complex systems produce order and to design governance systems that mimic or complement the ordering work of systems themselves" (p. 33), Burris et al. offer a nodal governance framework. As an extension of network theory, nodal framework "explains how a variety of actors operating within social systems interact along networks to govern the systems they inhabit (p.33)." Nodal theory posits that governance in such systems is substantially constituted in nodes - institutions with a set of technologies, mentalities and resources - that mobilize the knowledge and capacity of members to manage the course of events. Nodes are normally but not essentially points on networks, but networks are a prime means through which nodes exert influence. "A small local $\mathrm{NGO}$, for example, can spend a small amount of money, can use social capital to persuade to use a technology of problem solving, can give voice to local needs and mobilize local political pressure" (p.14).

Burris et al. are interested in how complex systems produce order and how to design governance systems that mimic or complement that ordering work of systems themselves. They argue that nodes develop as a strategic adaptation to complexity. Their theory provides an explanation of how social actions take place and how those within the networks end up responding to "marching orders" from governing nodes (p.12). This makes "super structural" nodes (e.g., state, government, large company) the command centres of networked governance. Nodes then, have the ability to govern a course of events, through connecting up networks. Nodal governance allows for a better understanding of the relationship between super-structural and other nodal actors within a network. That relationship must be complex, multi-directional. In other words, the local is a site of exchange between the top-down and bottom-up, as conduit for mutual influence, as a "messy" site that recognizes the limits of both state and local power.

Each node differs in its composition of capacities in technologies, mentalities and resources (see below). These characteristics have different effects on the status and efficacy of a node. The capacity of a node to regulate depends on its resources and connections. A theory of nodal governance, Burris et al. argue, can more accurately explain the role of the state and the tenuous quality of analysis rooted in hierarchy or public-private distinctions. To understand NGOs as sites of nodal governance helps uncover the power of local knowledge and capacity as an instrument of effective governance - from the bottom-up. 
A node "is a site within an organizing governing structure (OGS) where knowledge, capacity and resources are mobilized to manage a course of events" (ibid., pp. 37-38). A node, as site of governance has four essential characteristics:

- A way of thinking (mentalities) about the matters that the node has emerged to govern;

- A set of methods (technologies) for exerting influence over the course of events at issue;

- Resources to support the operation of the node and the exertion of influence;

- A structure that enables the directed mobilization of resources, mentalities and technologies over time (institutions) (Johnston and Shearing 2003).

Nodal governance therefore provides a potentially important framework in which the contribution of local actors to energy poverty governance can be understood. In keeping with the exploratory approach in this paper, focused on understanding an important emerging theme through the selection of illustrative examples, we now turn to suggest ways in which nodal governance can be applied in future research and to reflect on insights we draw from the preliminary data above.

\section{Reflections on Governing Energy Poverty: The Role of Local Nodes and Networks}

The examples we chose show how much variety there is in the approach to tackle energy poverty in each country. However, a common feature is a joining up of many actors (nodes) to form a larger network of support. We argue that this can be understood as symptomatic of two developments. First, an EU-wide "civil society" that aims to pick up the pieces from neoliberalism; and second, the undervalued role of community and civil society addressing energy poverty. We discuss the wider context of governance deficit through reflections on power and the debate between formal and informal policy interventions.

\section{Power}

The question of power is an important one if it equates to mobilizing resources and regulations to provide effective support for people living in energy poverty. Do the discussed networks change the location of state power, or even EU power? We see them as forming their own structure and governance, mobilizing others and forming a network that is united through a shared purpose. These can be formed apart from state power, or the state can be part of the network to mobilize resources and provide local validity of funding a project (e.g., Catalonia). These initiatives draw their power from being able to adapt, expand and react to local changes. They can also mobilize and grow their network to include some form of state power. Although in most cases the networks of nodes do not have formal legal state power, they have local power.

This lack of formal power also has downsides. It means that these networks make it part of their mission to fight energy poverty on the ground because of the lack of strong national (and EU level) support. They might be able to mobilise more resources and actors at the local level, removed from state power to provide tangible help. Their actual strength then lies in action at the local level and to tailor their initiatives to individual local needs and problem-solving. Here is where the networks vary - some of them do challenge the larger regulatory space and hold the powerful to account. 
A clear distinction between state actors (superstructural nodes) and local initiatives (nodes) becomes less obvious after considering a network and its power relations. We can argue here, that even if the network is set up to include some superstructural nodes, the work that is carried out on the ground is done by local initiatives. These are seen to be active and trusted within the local context, despite involvement or funding from formal channels.

\section{Informal Delivery of Formal Power?}

Are bottom-up initiatives controlled by top-down policy? Do the nodes deliver a truly bottom up service or are they driven by a different agenda? These questions are closely tied up with power, resources and politics. In the English and Catalan examples, the local action seems to be simply a palliative for the failure of the state to direct more powerful action to address market failures and inequalities arising from social injustice. This suggests that the third sector provides a bridge (very often state funded) to help access the local level, but this cannot take the place or adequately supplement for what is actually needed (i.e., more top down interventions). Often that bridge can be short term, project related and unstable.

Local initiatives that fight energy poverty can build networks to achieve their goals. These networks are of a varied set-up as seen above. They are usually made up of nodes with different sets of expertise, knowledge, resources and power. Here lies a strength: bottom-up initiatives can offer complex solutions for energy poverty and ensure to actively involve the affected individuals themselves. These local initiatives can also raise awareness of the issues in local, national and EU level policy agenda. They can connect more nodes to cooperate and thereby build a solid foundation to help people fight energy poverty, based on local success. "Local interventions, if they are well planned, can offer long-term solutions for households dealing with energy poverty. By presenting good practices that effectively decrease energy poverty, we would like to provide inspiration for decision makers and practitioners" (Bajomi 2016, p.169).

The question of power and top-down policy is an important one to consider. Local priorities and local action need to be supported by a formal web of regulations and policy. Only then can support grow into a larger space and become more organized and translated into wider action. Here is exactly where the challenge lies: The issue of energy poverty is too complex and multifaceted to be effectively addressed by national and EU actors, with issues of political will and problematic overlaps in policy responsibility standing in the way of more powerful action. Therefore, local initiatives can succeed on the ground, fuelled by delay in action from the top. Some initiatives, however, would not exist without funding from the top, they still fulfil a local function and are seen to be locally active, rather than state-incentivized.

Revisiting our argument about the governance deficit created by a slow EU and national policy response to the fast-growing problem of energy poverty, we find that bottom-up approaches fill a gap left by inaction of top down policies. The local is a flexible (albeit sometimes unstable) solution to address energy poverty on the ground and this paper seeks to help to understand their contribution better. Governance places a focus on institutions, social norms and social practises as mechanisms of social systems. A plurality of actors, mechanisms, and rapid adaptive change create new forms of social organization. It appears to be the solution to a problem caused by a remote state. Are these local solutions deemed to be a more transient, project focused solution? The local initiatives lack formal power to bring about change in the policy landscape.

A solution is offered by Middlemiss et al. (2018) through their five guiding principles to facilitate policy design, based on lived experiences. These broad principles are based on a 
multi-disciplinary understanding of energy poverty. They suggest, similarly to us in this paper, that the policy areas can be informed through different channels (subnational, national, and supranational). They base their recommendations on collective understandings of the possibilities of a more integrated approach to policy and practice:

Consider opportunities for joined-up and integrated policy;

Building momentum through networks and partnerships;

1. Expecting the unexpected;

2. Measuring progress holistically;

3. Just get on with it (Bajomi 2016).

Fighting energy poverty is an ongoing process. Caught in-between policy and disciplinary silos we tried in this paper to highlight the importance of the local. Despite significant national variations we find commonality in relation to the key findings about how local governance operates in this context and its importance. While we resist the idea of generalizing from this data, the exploratory findings suggest that similar phenomena are likely to exist across other European contexts and there is significant potential to follow this up in future research.

Acknowledgements We would like to thank Ian Loader for helpful comments on an earlier version of this paper. We are very grateful to our interviewees and workshop participants who have given their time and shared their valuable experiences with us. This work was supported by the Economic and Social Research Council [grant number ES/P010237/1].

\section{Compliance with ethical standards There are no conflicts of interest.}

Open Access This article is licensed under a Creative Commons Attribution 4.0 International License, which permits use, sharing, adaptation, distribution and reproduction in any medium or format, as long as you give appropriate credit to the original author(s) and the source, provide a link to the Creative Commons licence, and indicate if changes were made. The images or other third party material in this article are included in the article's Creative Commons licence, unless indicated otherwise in a credit line to the material. If material is not included in the article's Creative Commons licence and your intended use is not permitted by statutory regulation or exceeds the permitted use, you will need to obtain permission directly from the copyright holder. To view a copy of this licence, visit http://creativecommons.org/licenses/by/4.0/.

\section{References}

Bajomi, A. (2016). How to tackle energy poverty - good practice at local level. In K. Csiba (Ed.), Energy poverty handbook (pp. 169-181). The Greens/EFA Group in the European Parliament. Brussels: European Union.

Burnis, S., Kawachi, I., \& Sarat, A. (2002). Integrating law and social epidemiology. The Journal of Law, Medicine \& Ethics, 30, 510-521.

Canalenergia. (2019). Povertà energetica, un operatore sociale per superare la diffidenza del consumatore. Retrieved from https:/www.canaleenergia.com/rubriche/consumer/studi-e-proposte-per-affrontare-lapoverta-energetica-in-europa/ . Accessed 8 Jul 2019.

Catalan Law 22/2010, LLEI 22/2010, del 20 de juliol, del Codi de consum de Catalunya. Retrieved from http://portaljuridic.gencat.cat/ca/pjur_ocults/pjur_resultats_fitxa/?action=fitxa\&documentId=543841. Accessed 8 Jul 2019.

CLER. (2019). Loi énergie-climat: Tout reste à faire! Retrieved from https://cler.org/loi-energie-climat-tout-restea-faire/. Accessed 8 Jul 2019.

EPOV. (2019). Spain lays the foundations of its fight against energy poverty. Retrieved from https://www. energypoverty.eu/news/spain-lays-foundations-its-fight-against-energy-poverty . Accessed 8 Jul 2019. 
EU Energy Poverty Observatory. (2017). EU energy poverty observatory case study. Energy advice points. Retrieved from https:/www.energypoverty.eu/sites/default/files/downloads/publications/18-09/case_study_paes_barcelona.pdf. Accessed 8 Jul 2019.

Faiella, F., \& Lavecchia, L. (2014). Energy poverty in Italy (Bank of Italy, Economic Research and International Relations Area, Occasional Papers, 240).

Generalitat de Catalunya. (2015). Guia per a persones i famílies que tenen problemes econòmics per mantenir els subministraments d'aigua, llum i gas (Guide for people and families who have financial problems to maintain water, electricity and gas supplies). Retrieved from https://web.gencat.cat/web/shared/GENCAT/que_cal_ fer_si/serveis_centrals/que_fer_quan_especials/queferquan/pobresa-energetica/GUIA-POBRESAENERGETICA-doc_10638282_1.pdf. Accessed 8 Jul 2019.

HISPACOOP. (2017). Presentación del estudio 'consumidores vulnerables en el sector eléctrico. Retrieved from http://www.hispacoop.org/home/index.php/more-news-category/421-presentacion-del-estudioconsumidores-vulnerables-en-el-sector-electrico . Accessed 8 Jul 2019.

Italy's draft NECP (2019). Draft integrated national energy and climate plan. Ministry of Economic Development, Ministry of the Environment and Land and Sea Protection \& Ministry of Infrastructure and Transport. Retrieved from https://ec.europa.eu/energy/sites/ener/files/documents/ec_courtesy_translation_it_ necp.pdf . Accessed 8 Jul 2019.

Johnston, L., \& Shearing, C. (2003). Governing security: Explorations in policing and justice. London: Routledge.

Middlemiss, L., Gillard, R., Pellicer, V., \& Straver, K. (2018). Plugging the gap between energy policy and the lived experience of energy poverty: Five principles for a multidisciplinary approach. In C. Foulds \& R. Robison (Eds.), Advancing energy policy. Cham: Palgrave Pivot.

NEA Action for Warm Homes. (2016). Get warm soon? Progress to reduce ill health associated with cold homes in England. Retrieved from http://www.nea.org.uk/wp-content/uploads/2016/09/Get-Warm-Soon-report-incExec-Summary.pdf. Accessed 10 Jul 2019.

ONPE. (2019). 17 fiches descriptives des dispositifs d'aides existants. Retrieved from http://www.onpe. org/notes_de_lobservatoire/17_fiches_descriptives_des_dispositifs_daides_existants. Accessed 8 Jul 2019.

Pye, S. \& Dobbins, A. (2015). Energy poverty and vilnerable consumers in the energy sector across the EU: Analysis of policies and measures (Policy Report, May 2015). Retrieved from https://ec.europa. eu/energy/sites/ener/files/documents/INSIGHT_E_Energy\%20Poverty\%20-\%20Main\%20Report_FINAL. pdf. Accessed 10 Jun 2019.

Pye, S., Dobbins, A., Baffert, C., Brajkovic, J., Deane, P., \& DeMiglio, R. (2017). Energy poverty across the EU: policies and analysis. In M. Welsh, S. Pye, D. Keles, A. Faure-Schuyer, A. Dobbins, A. Shivakumar, P. Deane, \& M. Howells (Eds), Europe's energy transition: Insights for policy making. Amsterdam: Academic Press Elsevier.

Roche, D. (2002). Restorative justice and the regulatory state in South African townships. British Journal of Criminology, 42(3), 514-533.

Síndic de Greuges de Catalunya (Catalan Ombudsman). (2018). El Síndic reclama que se simplifiqui el procediment per sol-licitar el nou bo social i se'n concreti l'abast entre la població vulnerable. Retrieved from http://www.sindic.cat/ca/page.asp?id=53\&ui=4962 . Accessed 8 Jul 2019.

The Right to Energy Coalition. (2019). Our energy system isn't working - let's fix it. Retrieved from http://righttoenergy.org. Accessed 8 Jul 2019. 


\section{Legislation}

EU

Directive 2018/2002 on Energy Efficiency

Governance Regulation 2018/1999

Third Energy Package directives 2009/72/EC and 2009/73/EC

\section{England}

Fuel Poverty Regulations 2014

Care Act 2014

Italy

Law n $2010-788$ of 12 July 2010

Reddito di cittadinanza entered into force in April 2019

Spain

Law 24/2013 of the electricity sector

Royal Decree 897/2017

\section{Catalonia}

2015 Catalan law 24/2015 on energy poverty goes further,

The Consumer Code (Codi de Consum) Catalan Law 22/2010, LLEI 22/2010

Publisher's Note Springer Nature remains neutral with regard to jurisdictional claims in published maps and institutional affiliations. 